\title{
İş Sağlığı ve Güvenliği Ön Lisans Programında Verilen Eğitim ve Öğretimin İş Sağlığı ve Güvenliği Alg1sı Üzerine Etkisi
}

\author{
DOI: 10.26466/opus.565166 \\ * \\ Turan Șahmaran $^{*}$ - Hatice Kar** ${ }^{*}$ İbrahim Arısal ${ }^{* * *}$
}

* Öğr. Gör., Hatay Mustafa Kemal Üniversitesi, Kırıkhan Meslek Yüksekokulu, Hatay/Türkiye

E-Posta: tsahmaran@gmail.com

ORCID: 0000-0003-3708-6162

** Öğr. Gör., Hatay Mustafa Kemal Üniversitesi, Kırıkhan Meslek Yüksekokulu, Hatay/Türkiye

E-Posta: haticekar@mku.edu.tr

ORCID: 0000-0002-4526-8794

***Dr. Öğr. Üyesi., Hatay Mustafa Kemal Üniversitesi, Kırıkhan Meslek Yüksekokulu, Hatay/Türkiye

E-Posta: iarisal@mku.edu.tr

ORCID: 0000-0002-9194-5784

\section{Öz}

Bu araştırma, Hatay Mustafa Kemal Üniversitesi İş Sağlı̆̆ı ve Güvenliği Önlisans Programında, öğrencilerin iş sağglı̆̆ı ve güvenliğine bakış açılarının eğitim ve öğretim süreci sonucunda nasıl değiştiğini değerlendirmek amacıyla yapılmıştır. Araştırmada nicel araştırma yöntemlerinden tarama modeli kullanılmıştır. Araştırmanın evrenini Hatay Mustafa Kemal Üniversitesi'nde İş Sağlığı ve Güvenliği Önlisans Programında okuyan 2. sinıf öğrencileri ile bu programa yeni başlayan 1. sınıf öğrencileri oluşturmaktadır. Araştırmanın örneklemini 61 öğrenci oluşturmaktadır. Araştırmada veri toplamak amacıyla "Üniversite Öğrencilerinin Sosyal Güvenlik Algıları" ölçeği kullanılmıştır. Araştırmada kullanılan ölçek beşli likert tipindedir. Araştırmadan elde edilen veriler "SPSS for Windows 22,0" programı kullanılarak analiz edilmiştir. Araştırmada iki bağımsız grup arasında farkın önemini test etmek için Mann-Whitney U Testi seçilmiştir. Çalışmanın sonuçlarına göre, 2. sınıf öğrencileri ile 1. sınıf öğrencileri arasında iş sağlı̆̆ı ve güvenliği algısına ilişkin anlamlı bir fark olduğu tespit edilmiştir. Ayrıca 2. sinıfta bulunan öğrencilerin iş sağhlğ̆ ve güvenliği algısının 1. simflara göre daha yüksek olduğu sonucuna ulaşılmıştır. Bu yüksekliğin nedeninin birinci sımıfta aldıkları dersler ve eğitim olduğu söylenebilir.

Anahtar Kelimeler: İş Sağglı̆̆ı ve Güvenliği, Meslek Yüksekokulu, Tutum ve Farkındalık 


\title{
Effect of Education and Training Given in the Occupational Health and Safety Associate Degree Program on the Perception of Relation Between Occupational Health and Safety
}

\begin{abstract}
This study was carried out in Hatay Mustafa Kemal University Vocational Health and Safety Associate Degree Program in order to evaluate how the viewpoints perspective on occupational health and safety changed as a result of the education and training process. The universe of the research is composed of second class students studying in the mentioned program and at the same time the first class students who are new to this program. The sample of the study consisted of 61 students. In order to collect the data of the study, "Social Security Perceptions of University Students Scale" was used. The scale used in the research is five-point Likert type. The data obtained from the study were analyzed by using "SPSS for Windows 22.0 program. Mann-Whitney $U$ Test was chosen to test the significance of the difference between two independent groups. According to the results of the study, it was determined that there was a significant difference in occupational health and safety perception between 2 nd year students and 1st grade students. Moreover, it was concluded that the occupational health and safety perception of the students in the second year is higher than the 1st grade students. In this study, it can be said that the reason for this height is the lessons and education they took in the first grade.
\end{abstract}

Keywords: $\quad$ Occupational Health and Safety, Vocational High School, Attitude and Awareness 


\section{Giriş}

21. yüzyıldaki işler, hizmet ve bilgi sektörlerindeki genişleme, küçük işletme sayısındaki artış, geleneksel olmayan iş programları, güvencesiz işçiler, işçi hareketliliği ve yaşlı çalışanlarla karakterize edilmiştir (Neira, 2010, Stellman, 2012). Bu özellikler, yeni işle ilgili bozukluklar, bulaşıcı olmayan hastalıklar ve iş sağlı̆̆ hizmetlerinin mevcudiyetindeki eşitsizlik de dahil olmak üzere, çalışanların sağlığı ile ilgili yeni sorunların ortaya çıkmasına yol açmıştır (WHO, 1995, 2013). Bu yeni ve ortaya çıkan sorunların üstesinden gelmek ulusal düzeyde bir eğitim ve önleme kültürünü gerektirir.

Üniversitelerin lisans ve önlisans programlarının birçoğunda iş sağllğ ve güvenliği dersleri seçmeli veya zorunlu olarak verilmektedir. Bu dersler öğrencilerde iş sağ lı̆̆ 1 ve güvenliği farkındalığı yaratması açısından oldukça önemlidir. Eğitim yoluyla yapılan bu farkındalık öğrencilerin iş hayatındaki önleme kültürünü ortaya çıkarmaya yardımcı olmaktadır. Önleme kültürünün oluşması eğitimle paralel olarak sağlanmaktadır. İş kazası ve meslek hastalığının en önemli nedenlerinden birisini eğitimsizlik oluşturmaktadır. Yapılan iş konusunda gerekli bilgi ve donanıma sahip olmayan kişiler iş yerinde güvensiz davranışlara neden olabilmektedirler. Güvensiz davranışların neticesinde iş kazaları kaçınılmaz olmaktadır. Uluslararası Çalışma Örgütü (ILO)'nün 2002 yılında hazırladığı Güvenlik Kültürü Raporuna göre meslek hastalıklarının tümü ve iş kazalarının \% 98'i önlenebilir kazalardır (Yılmaz, 2014).

İş kazaları genellikle, eğitim eksikliği, denetimlerin usulüne uygun gerçekleşmemesi, makine ve teçhizatın periyodik bakımlarının zamanında yapılmaması, çalışanların işe karşı yargısı, bununla birlikte dikkatsizlik ve ilgisizliğin ortaya çıkması gibi sorunlardan kaynaklanmaktadır (Sawacha ve ark., 1999). Bu sorunların ortadan kaldırılması ve gerekli önlemlerin alınması (bu önlemlerin başında eğitim ve denetim gelmektedir) ile iş kazası ve meslek hastalıklarının önemli oranda azalacağını gerek İLO'nun yapmış olduğu çalışmalar gerekse bu alanda yapılan akademik veriler göstermektedir. Kişiler yoğun çalışma temposu ile birlikte sağlık ve güvenlik tehlikelerini de beraberinde getirmektedir (Erkan, 2001). Bu tehlikeler çalışanın sağlığını direkt etkileyebilecek iş kazaları ve meslek 
hastalıklarını içermektedir (Parlar, 2008, Kalkış ve Demir, 2012, Güvercinci, 2005). İş kazaları ve meslek hastalıklarının görülme sıklığı, bilim ve sanayideki gelişmeleri takiben belirgin bir şekilde azalmıştır. Bu gelişmelere kişisel koruyucu donanımların kullanımı, mühendislik kontrolleri, iş teftişleri ve yönetmelik uygulamaları ve iş sağlığı ve güvenliği konusundaki eğitimler örnek verilebilir (Hale ve Hovden, 1998). ILO ayrıca, iş sağlığ ve güvenliği yönetiminin işletme içinde önleme kültürünü destekleyen kilit bir unsur olduğunu belirtmiştir (ILO, 2009).

İş hayatındaki malzeme, ürün ve hizmetlerin sağlıklı bir şekilde üretilip sürdürülebilmesi için devlet ve işveren tarafından çalışan nüfusunun sağlığı, güvenliği ve refahı göz ardı edilmemelidir. Ayrıca, yaşam süresinin uzaması ile birlikte uzun çalışma hayatında çalışanlar risklere daha uzun süre maruz kalmaktadır. Bunu önlemek için çalışma hayatı boyunca sürdürülebilir eğitim yaklaşımlarının iş hayatına uyarlanması giderek önem kazanmaktadır (Boileau, 2016).

Bir mesleği veya ticareti öğrenmek karmaşık bir süreçtir. Güvenli ve sağlıklı iş uygulamalarının kullanılmasını sağlamak için bilgi edinme ve paylaşmanın sürdürülebilir olması gerekmektedir. Bu sürdürülebilirlik için ilkokuldan üniversite eğitimine kadar geçen sürede bireylerin İSG konusundaki farkındalıklarının olması gerekmektedir. Eğitim, çalışanların davranışında istenen yönde değişiklik oluşturma süreci olup iş kazası ve meslek hastalıklarının önüne geçmede en önemli etkenlerden bir tanesidir (Savcı ve ark., 2018).

Ülkemizde İSG eğitimi Aile, Çalışma ve Sosyal Hizmetler Bakanlığı tarafından yetkilendirilen eğitim kurumları, üniversiteler ve iş yerindeki çalışanlara verilen eğitim üzerinden devam etmektedir. Üniversitelerin İSG alanındaki sorunları akademik düzeyde ele alıp sorunların çözümünde bilimsel bir rol oynaması üniversite düzeyindeki eğitimin gerekliliğini göstermektedir. Günümüzde almış olduğu İSG eğitimini iş sahasında kullanabilecek nitelikli elemanlara ihtiyaç vardır. Bu da meslek yüksekokullarına gereksinimi arttırmaktadır. Çalışmalar göstermiştir ki İSG konusunda verilen eğitim ile birlikte bireyler oluşabilecek kazaları daha iyi tahmin edebilmektedir (Asepatori, 2011). Verilen etkili bir eğitim sonucunda kaza, yaralanma, yasal sorumluluk ve işçilerin tazminat talebi sayısı azalt1labilir (Othman, 2012). 
Meslek yüksekokullarının kuruluş amacı; meslek alanında endüstrinin istediği bilgi ve beceriye sahip, çalıştığı iş yerlerinde insanlarla kolay diyalog kurabilen, temel seviyede yabanci dil bilen, bilgisayar kullanabilen, doğrudan ve dolaylı olarak sosyal ve kültürel olaylara katkı sağlayabilen ara insan gücünün yetiştirilmesidir (Görmüş ve Bektaş, 2002). Meslek yüksekokullarında, mesleki eğitim öğrencileri, okulda gördükleri dersleri çalışacakları alanlarda uygulamalı olarak da gördüklerinden dolayı iş güvenliği konusunda bilgi ve beceri yönünden yeterlilik sahibi olmaları gereklidir (Akalp ve Karadeniz, 2013).

Yapılan araştırmalar işgücü gereksiniminin dörtte üçünün önlisans düzeyinde eğitimle yetiştirilmesi gerektiğini ortaya koymaktadır (Özgüler ve Koca, 2013). Ayrıca Ceylan (2012) çalışmasında İSG eğitiminin gerekliliğini ortaya koymuş ve meslek yüksekokullarında bu eğitimin önemini dile getirmiştir. Bu çalışmada amaç, Hatay Mustafa Kemal Üniversitesi İSG Önlisans Programında okuyan 2. sınıf öğrencileri ile bölüme yeni gelmiş ve henüz İSG konusunda bölümden ders almamış 1. sınıf öğrencilerinin İSG'ye bakış açılarının eğitim ve öğretim süreci sonucunda nasıl değiştiğini değerlendirmektir. Bu çalışma öğrencilerin vermiş oldukları cevaplar doğrultusunda İSG alanında verilen eğitimin etkinliğinin incelenmesi ve gözden geçirilmesine olanak sağlamıştır. Çalışmaya başlamadan önce 26.09.2018 tarih ve 04 sayılı karar ile Hatay Mustafa Kemal Üniversitesi Sosyal ve Beşeri Bilimler Bilimsel Araştırma ve Yayın Etiği Kurulundan çalışmanın etik kurulu alınmıştır.

\section{Yöntem}

Bu bölümde; araştırma modeli, araştırmanın evreni ve örneklemi, veri toplama aracı, verilerin toplanması ve veri analizi sunulmuştur.

\section{Araştırma Modeli}

Bu araştırmada 1. ve 2. sınıf İSG programı öğrencilerinin iş sağlığı ve güvenliğine ilişkin görüşleri belirlenmeye çalışılmıştır. Mevcut durum göz önüne alınarak araştırmada nicel araştırma modellerinden tarama modeli kullanılmıştır. Burns ve Grove (1993) nicel araştırmayı, yaşadığımız 
dünya hakkında bilgi elde etmek amacıyla sayısal verilerin formal, objektif ve sistematik bir süreci olarak ifade etmiştir. Tarama araştırması bir konuya ya da olaya ilişkin katılımcların görüşlerinin ya da ilgi, beceri, yetenek, tutum vb. özelliklerinin belirlendiği araştırma türüdür (Büyüköztürk, 2010).

\section{Araştırmanın Evreni ve Örneklemi}

Araştırmaya 1. ve 2. sınıfta bulunan tüm öğrenciler dahil edilmiştir. Araştırmayı 2. sınıfta 24,1. sınıfta ise 37 öğrenci olmak üzere toplam 61 öğrenci örneklemi oluşturmaktadır. Örneklem içerisinde yer alan katılımcların \% 44,3'ü kız öğrenci, \% 55,7'si erkek öğrenciden oluşmaktadır, Katılım sağlayan öğrencilerden \%23,0 meslek lisesi, \% 18,0 sağlık meslek lisesi, \% 21,3 düz lise ve \% 37,7 diğer lise (Anadolu lisesi vb,) mezunudur, İş sağlı̆̆ ve güvenliği önlisans programını tercih ederken bölüm hakkında bilgisi olanların \% 42,6 bilgisi olmayanların \% 57,4 olduğu görülmüştür, İSG programına başlamadan önce çalışma hayatında veya herhangi bir eğitim esnasında İSG eğitimi alan öğrenciler \%27,9, eğitim almayan öğrenciler \% 72,1 olarak tespit edilmiştir. Ayrıca 1. ve 2. sınıfların \% 98,4'ü yaş ortalaması 18-24 yaş aralığında olup \% 1,6'sı 25-31 yaş aralığındadır.

\section{Veri Toplama Aracı}

Hatay Mustafa Kemal Üniversitesi'nde İSG programına kayıtlı 1. ve 2. s1nıf öğrencilerinin verilen eğitim ile iş sağlı̆̆ 1 ve güvenliği konularına bakış açlarının nasıl değiştiğinin belirlenmesi için veri toplamak amacıyla Eraslan'ın (2015) “Üniversite Öğrencilerinin Sosyal Güvenlik Algıları" isimli çalışmasındaki ölçek kullanılmıştır. Araştırmanın verileri geçerlik ve güvenirlik çalışmalarını yaptığı ölçek (Topgül ve Alan, 2017) aracılığıyla elde edilmiştir. İlgili ölçek 20 maddeden oluşmaktadır. Araştırmada kullanılan ölçek beşli likert tipindedir. Ölçek maddelerine ilişkin puanlar "Kesinlikle Katılmıyorum" (1)'den "Kesinlikle Katılıyorum" (5)'e kadar farklılık göstermektedir. Uygulaması, kodlaması ve ölçmesinin kolay olması, farklı sayıda seçenek kullanımına izin vermesi, seçeneklerin etiketlenmesinde araştırmacılara serbestlik tanıması ve katılımcılar için kolay anlaşılır ol- 
ması (Tavakoli, 2012, Spector, 1992), tutum ve görüş araştırmalarında Likert-tipi soruların sıklıkla kullanılmasını sağlamıştır. Likert tipi sorular ordinal veri olarak kabul edildiğinden bu sorulardan elde edilen verilerin istatistiksel analizinde parametrik olmayan istatistiksel testlerin kullanılması gerekmektedir (Turan ve ark., 2015).

\section{Verilerin Toplanması}

Her bir katılımcıya çalışmanın amacı hakkında kısaca bilgi verilmiştir. Uygulanan ölçekler, araştırmacılar tarafından katılımcılara verilmiş olup doldurulmuş ölçekler, aynı gün içinde araştırmacılar tarafından tekrar alınmıştır.

\section{Verilerin Analizi}

$\mathrm{Bu}$ araştırma kapsamında Kaiser-Meyer-Olkin (KMO) değerinin 0,691 ve Barlett testi sonucunun anlamlı olduğu görülmüştür. Dolayısıyla araştırma verilerinin faktör analizi için uygun olduğu ortaya koyulmuştur. Açımlayıc faktör analizinde, ölçeğin tek boyutlu orijinal formu elde edilmiştir. Bu tek boyutun, ölçme aracındaki toplam varyansın \% 26,69'unu açıkladığı görülmüştür. Verilerin güvenilirliğini test etmek amacıyla Cronbach alfa $(\alpha)$ güvenirlik analizi yapılmıştır. Tüm maddeler için elde edilen $\alpha$ değeri o ölçeğin toplam güvenirliğini gösterir ve genel kabul bu değerin 0,7 ve büyük olmasıdır (Kılıç, 2016). Ayrıca Alpar (2016) güvenilirlik katsayısının 0,8-1,0 arasında olması durumunda, ölçeğin güvenirliğinin yüksek olduğunu söylemektedir. Araştırmanın veri setiyle Cronbach alfa katsayısı 0,720 olarak hesaplanmıştır. Cronbach alfa güvenilirlik analizi her bir ölçek sorusu için saptanan tek bir $\alpha$ değeri olabileceği gibi, ölçekteki tüm maddelere ait ortalama bir $\alpha$ değeri de olabilir. Çalışmada istatiksel analizler için örneklemin kısıtlılığı ve yapılan normallik testi sonuçlarından verilerin normal dağılmadığı anlaşıldığından parametrik olmayan testler uygulanmıştır. İki bağımsız grup arasında farkın önemini test etmek için Mann-Whitney U Testi seçilmiştir. Araştırmadan elde edilen veriler SPSS (Statistical Package for Social Sciences) for Windows 22,0 programı kullanılarak analiz edilmiştir. Araştırmanın hipotezleri şu şekildedir; 
- $\quad$ H0 = İş sağlığ1 ve güvenliği önlisans programı 2. sınıf öğrencileri ile 1 . sınıf öğrencileri arasında iş sağlığı ve güvenliği algısına ilişkin anlamlı bir fark yoktur.

- H1= İş sağlı̆̆1 ve güvenliği önlisans programı 2.sınıf öğrencileri ile 1.sınıf öğrencileri arasında iş sağlığı ve güvenliği algısına ilişkin anlamlı bir fark vardır.

\section{Bulgular}

Bu bölümde araştırmaya katılan öğrencilere ilişkin tanımlayıcı istatistiklere yer verilmiştir. Bu bilgiler doğrultusunda iki ayrı sınıfta yer alan öğrencilerin iş sağlığı ve güvenliği önlisans programı 2. sınıf öğrencileri ile 1.sınıf öğrencilerinin iş sağlığı ve güvenliği algısına ait analiz sonuçları ve bunların yorumlanması bulunmaktadır. Araştırma ile elde edilen verilerin analizi sonucunda ulaşılan bulgular aşağıda tablolar halinde sunulmaktadır. Tablo 1'de demografik bilgiler yer almaktadır.

Tablo 1. Katılımcıların Demografik Özellikleri

\begin{tabular}{lcc}
\hline Cinsiyet & 1. Sınıf $\mathbf{n}(\%)$ & 2. Sinıf $\mathbf{n}(\%)$ \\
\hline Erkek & $21(56,7)$ & $13(54,2)$ \\
Kadın & $16(43,3)$ & $11(45,8)$ \\
Lise Mezuniyet & & \\
Düz Lise & $6(16,2)$ & $7(29,2)$ \\
Meslek Lisesi & $7(18,9)$ & $7(29,2)$ \\
Sağllk Meslek Lisesi & $6(16,2)$ & $5(20,8)$ \\
Diğer Lise (Anadolu, vb.) & $18(48,7)$ & $5(20,8)$ \\
İSG bölümü hakkında bilgi & Evet & Hayır \\
& $26(42,6)$ & $35(57,4)$ \\
ISGG eğitimi daha önce aldınız mı & Evet & Hayır \\
& $17(27,9)$ & $44(72,1)$ \\
\hline
\end{tabular}

Verilen cevaplar SPSS' de incelendiğinde her iki test sonucunda da dağılımin normal olmaması $(p<0,05)$ nedeniyle verilerin analizinde parametrik olmayan testler kullanildı.

Tablo 2. İş Sağllğı ve Güvenliği Algısına İlişkin Mann-Whitney U Testi Sonuçları

\begin{tabular}{lllllll}
\hline Grup & $\mathbf{n}$ & Siralar ort. & $\begin{array}{l}\text { Siralar } \\
\text { top. }\end{array}$ & $\begin{array}{l}\text { Mann- } \\
\text { Whitney U }\end{array}$ & $\mathbf{z}$ & $\mathbf{p}$ \\
\hline 1. Sinif & 37 & 23,84 & 882 & 124,5 & $-3,919$ & 0,006 \\
2. Sinif & 24 & 42,04 & 1009 & & & \\
\hline
\end{tabular}


Çalışmanın hipotezlerinin test edilip, desteklenip desteklenmediğinin belirlenmesi amacıyla Tablo 2'deki Mann-Whitney U testine ilişkin bulgulara bakılmıştır. Buna göre iş sağlığg ve güvenliği öğrencilerinin dahil oldukları sınıflar arasında iş sağlığı ve güvenliği algısına ilişkin anlamlı bir fark olduğu anlaşılmaktadır ( $U=124,50, p=0,006$; $p<0,05)$. Tablo 2'de bu farklılığın boyutlarına bakıldığında ise sıra ortalamaları dikkate alınd1ğında 2. sınıf öğrencilerinin iş sağlığı ve güvenliği alg1sı 1. sınıf öğrencilerden daha yüksek olduğu anlaşılmaktadır. Bu kapsamda çalışmanın hipotezini oluşturan iş sağlığı ve güvenliği önlisans programı 2. sınıf öğrencileri ile 1.sınıf öğrencileri arasında iş sağlı̆̆ı ve güvenliği algısına ilişkin anlamlı bir fark vardır, ifadesi desteklenmiştir. Bu durumda H1 hipotezi reddedilirken, H0 hipotezi kabul edilir. Tablo 3’ de ölçek soruları verilmiştir.

Tablo 3. Kullanılan ölçek maddelerinin tanımlayıcı istatistikleri

\begin{tabular}{|c|c|c|}
\hline Ifadeler & $\begin{array}{l}\text { Orta- } \\
\text { lama }\end{array}$ & $\begin{array}{l}\text { Std. } \\
\text { Sapma }\end{array}$ \\
\hline 1. İSG ile ilgili yasal mevzuatları biliyorum. & 3,11 & 0,915 \\
\hline $\begin{array}{l}\text { 2. Türkiye'de İSG uygulamalarının yeterli olduğunu düşünüyo- } \\
\text { rum. }\end{array}$ & 2,31 & 1,133 \\
\hline $\begin{array}{l}\text { 3. İSG kurallarından bazılarının iş verimini azalttığını düşünü- } \\
\text { yorum. }\end{array}$ & 2,43 & 1,310 \\
\hline $\begin{array}{l}\text { 4. Türkiye'de İSG ihlallerine dönük yaptırımların neler oldu- } \\
\text { ğunu biliyorum. }\end{array}$ & 3,23 & 0,673 \\
\hline $\begin{array}{l}\text { 5. İşimden olmamak (atılmamak) için, bazen İSG kurallarına uy- } \\
\text { mayabilirim. }\end{array}$ & 2,32 & 1,396 \\
\hline $\begin{array}{l}\text { 6. İşyerindeki çalışma şartlarının iyileşmesinde İSG eğitimlerinin } \\
\text { etkisinin fazla olduğunu düşünüyorum }\end{array}$ & 3,75 & 1,260 \\
\hline $\begin{array}{l}\text { 7. İSG konusunda aldığım eğitimi çalışma hayatımda uygulaya- } \\
\text { cağımı düşünüyorum }\end{array}$ & 3,95 & 1,309 \\
\hline $\begin{array}{l}\text { 8. İSG için sadece ön lisans değil lisans, yüksek lisans ve doktora } \\
\text { düzeyinde de eğitim verilmesi gerektiğini düşünüyorum. }\end{array}$ & 3,61 & 1,255 \\
\hline 9. İSG'nin sağlanması temel insan haklarından biridir. & 4,02 & 1,204 \\
\hline $\begin{array}{l}\text { 10. İSG'nin ortaöğretim ve lise müfredatında yer alması gerekti- } \\
\text { ğini düşünüyorum. }\end{array}$ & 3,28 & 1,293 \\
\hline $\begin{array}{l}\text { 11. İSG eğitimlerinin ve yasal mevzuatın iş kazalarını ve meslek } \\
\text { hastalığını azalttığını düşünüyorum }\end{array}$ & 4,26 & 1,139 \\
\hline $\begin{array}{l}\text { 12. Her iş yeri, aldığ işçiye işe başlatmadan önce işçi sağlığı ve } \\
\text { güvenliği eğitimini vermesi gerektiğini düşünüyorum. }\end{array}$ & 4,21 & 1,226 \\
\hline 13. Türkiye'de İSG kültürünün oluştuğunu düşünüyorum. & 2,75 & 1,114 \\
\hline
\end{tabular}


14. Başka bir programı kazanmış olsaydım bile İSG dersinin ka- $\quad 3,36 \quad 1,141$ zandığım programda zorunlu olmasını isterdim.

15. İSG bölümünde okutulan müfredatın İSG farkındalığı konu- $\quad 3,37 \quad 0,974$ sunda yeterli olduğunu düşünüyorum.

$\begin{array}{lll}\text { 16. ISG kanunun ertelenmesini doğru bulmuyorum. } & 3,73 & 1,339\end{array}$

17. Sadece teorik dersler değil iş hayatına uygun pratik $4,20 \quad 0,928$ derslerinde programda yer alması gerektiğini düşünüyorum.

18. 331 sayılı yasanın İSG'nin uygulanması açısından yeterli $3,21 \quad 0,933$ olduğunu düşünüyorum.

19. Türkiye'de çalışanların maruz kaldıkları riskler ve bunlarla baş etme yollarında etkin eğitim aldıklarınıdüşünmüyorum.

20. İSG'nin yalnız çalışma ortamında değil, hayatın her 3,11 aşamasında olması gerektiğini düşünüyorum.

Tablo 3'te verilen ifadelerinden birincisi, "ISG ile ilgili yasal mevzuatları biliyorum" sorusudur. Bu soruya Şekil 1a'da, 1. sınıf öğrencilerinde fikrim yok cevabı baskınken şekil 1b'de 2. sınıf öğrencilerinin katılıyorum cevabı baskındır. 2. sınıf öğrencilerinin yasal mevzuat derslerini görmesi bu sonuçta etkili olduğunu göstermektedir $(\mathrm{p}<0,05)$. Ortalama değer 1 . sınıflarda 2,73 iken 2. sınıflarda 3,71 olarak çıkmıştır.

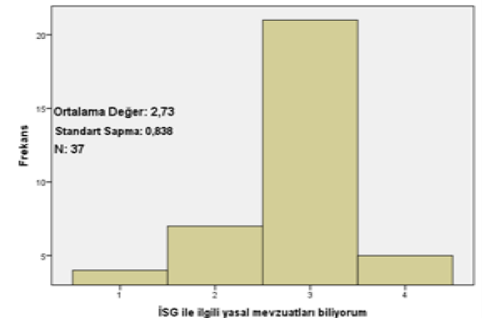

Şekil 1a. Birinci sınıf cevap dağılımı

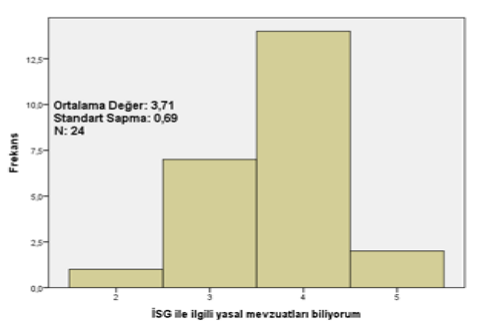

Şekil 1b. İkinci sınıf cevap dă̆̊lımı

Sorulardan ikincisi, "Türkiye'de İSG uygulamalarının yeterli olduğunu düşünüyorum" sorusudur. Bu soruda 1. sınıf öğrencilerinde katılmıyorum ve tamamen katılıyorum cevapları baskınken 2 . sınıf öğrencilerinde katılmıyorum cevabı baskındır. İSG uygulamaları konusunda istatistiki anlamlılık bulunmamaktadır ( $>00,05)$. Ortalama değer 1. sinıflarda 3,43 iken 2. sınıflarda 3,25 olarak çıkmıştır. Şekil $2 a$ ve $2 b^{\prime}$ de görsel sonuçlar gösterilmiştir. 


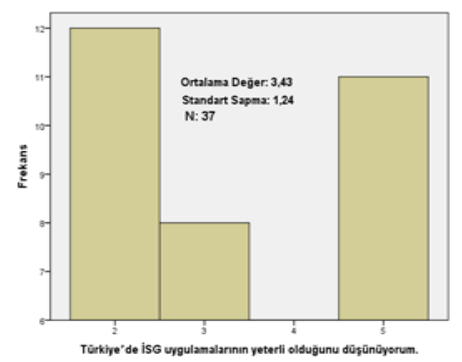

Şekil 2a. Birinci sınıf cevaap dağılımı

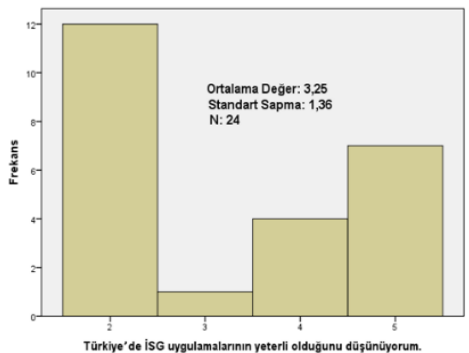

Şekil 2b. İkinci sınıf cevap dă̆ılımı

Sorulardan üçüncüsü, "ISSG kurallarından bazılarının iş verimini azalttığını düşünüyorum" sorusudur. Bu soruda 1. sınıf öğrencilerinde katılm1yorum ve fikrim yok cevapları baskınken 2. sınıf öğrencilerinin tamamen katılıyorum ve kısmen de olsa katılmıyorum cevapları baskındır. Üçüncü soru için istatistiki olarak anlamlı bir farkın olmadığ görülmüştür ( $p>0,05)$. Ortalama değer 1. sinıflarda 3,22 iken 2. sinıflarda 4,04 olarak çıkmıştır. Şekil 3a ve 3b'de görsel sonuçlar gösterilmiştir.

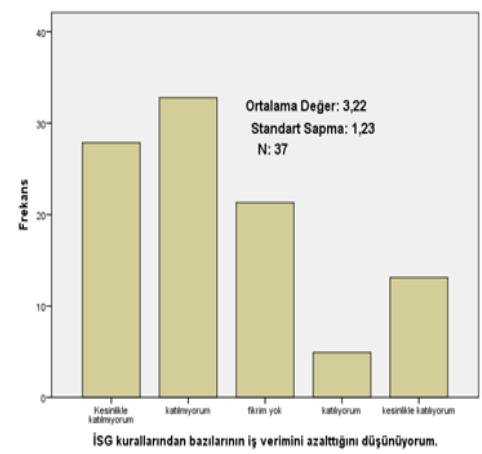

Şekil 3a. Birinci sınıf cevap dă̆ılımı

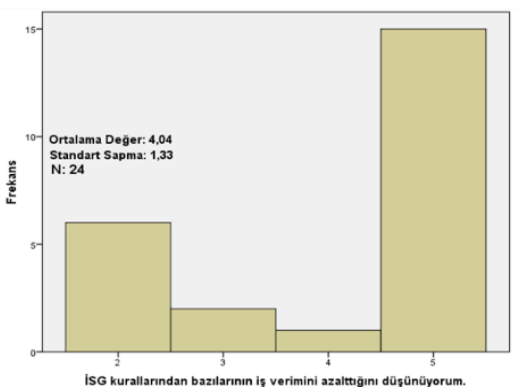

Şekil 3b. İkinci sınıf cevap dă̆̊lımı

Sorulardan dördüncüsü, "Türkiye'de İSG ihlallerine dönük yaptırımların neler olduğunu biliyorum" sorusudur. Bu soruda 1. sinıf öğrencilerinde fikrim yok cevabı baskınken 2. sınıf öğrencilerinin fikrim yok ve katılıyorum cevapları baskındır. Yaptırımların neler olduğu konusunda istatistiksel olarak anlamlı bir farkın olduğu görülmüştür $(p<0,05)$. Ortalama değer 1. sinıflarda 3,05 iken 2. sinıflarda 3,50 olarak çıkmıştır. Şekil 4a ve $4 b^{\prime}$ de görsel sonuçlar gösterilmiştir. 


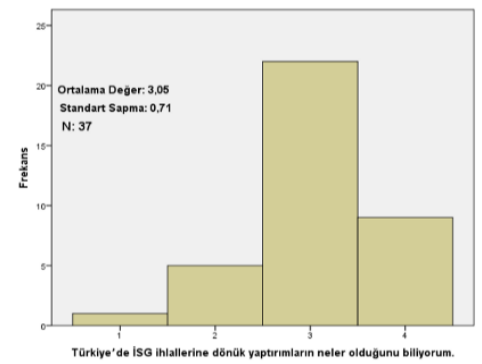

Şekil 4a. Birinci sınıf cevap dağılımı

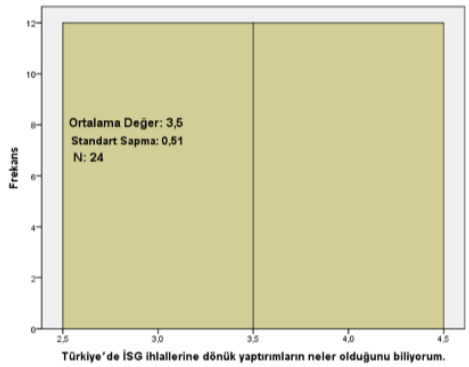

Şekil 4b. İkinci sınıf cevap dağılımı

Sorulardan beşincisi, “işimden olmamak (atılmamak) için, bazen İSG kurallarına uymayabilirim" sorusudur. Bu soruda 1. sınıf öğrencilerinde tamamen katılmıyorum, katılmıyorum cevapları baskınken diğer cevaplarında sayısı azımsanmayacak kadar fazla olduğu görülmektedir. 2. sınıf öğrencilerinde tamamen katılmıyorum, katılmıyorum cevapları baskınken, 1. sınıf öğrencilerine göre diğer cevapların daha az olduğu görülmektedir. İSG kurallarına işimden olmamak için uymayabilirim sorusunda istatistiksel olarak anlamlı bir farkın olmadığ görülmüştür ( $p>0,05)$. Ortalama değer 1. sınıflarda 2,59 iken 2. sınıflarda 1,92 olarak çıkmıştır. Şekil 5 a ve $5 b^{\prime}$ de görsel sonuçlar gösterilmiştir.

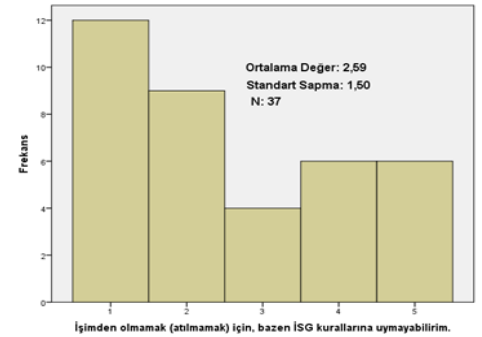

Şekil 5a. Birinci sımıf cevap dağılımı

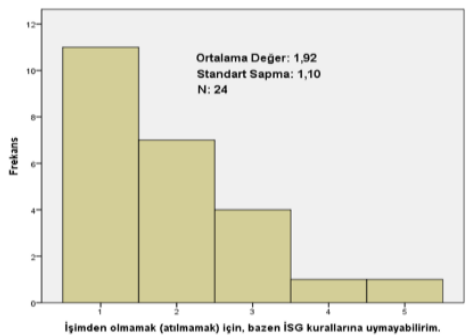

Şekil 5b. İkinci sınıf cevap dă̆ılımı

Sorulardan altıncısı, "işyerindeki çalışma şartlarının iyileşmesinde İSG eğitimlerinin etkisinin fazla olduğunu düşünüyorum" sorusudur. Bu soruda 1. sınıf öğrencilerinde katılıyorum cevabı baskınken 2. sınıf öğrencilerinde tamamen katılıyorum cevabı baskındır. İSG eğitimlerinin etkisi sorusunda istatistiksel olarak anlamlı bir farkın olmadığı görülmüştür (p>0,05). Ortalama değer 1. sinıflarda 3,54 iken 2. sinıflarda 4,08 olarak çıkmıştır. Şekil $6 a$ ve $6 b^{\prime}$ de görsel sonuçlar gösterilmiştir. 


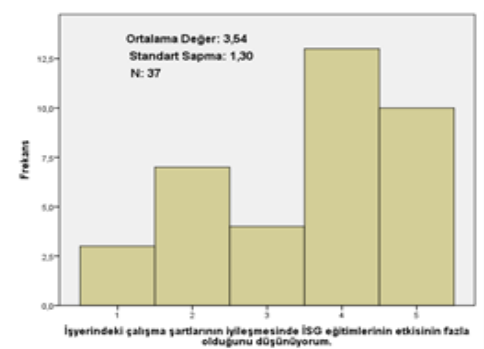

Şekil 6a. Birinci sınıf cevap dă̆ılımı

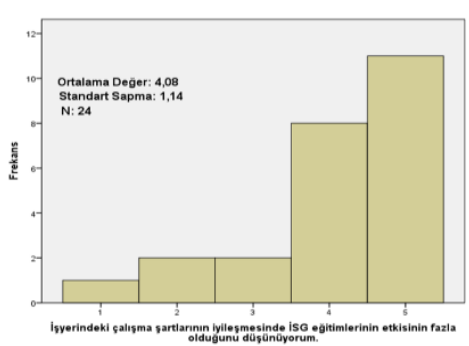

Şekil 6b. İkinci sınıf cevap dă̆ılımı

Sorulardan yedincisi, "İSG konusunda aldığım eğitimi çalışma hayatımda uygulayacağımı düşünüyorum" sorusudur. Bu soruda 1. sınıf öğrencilerinin büyük bir kısmı tamamen katılıyorum dese de tamamen katılmıyorum cevabı da oldukça fazladır. 2. sınıf öğrencilerinde ise tamamen katıl1yorum cevabı baskın olup tamamen katılmiyorum ve katılmıyorum cevabı bulunmamaktadır. Alınan eğitimin çalışma hayatına uygulanacağ 1 sorusunda istatistiksel olarak anlamlı bir farkın olduğu görülmüştür $(p<0,05)$. Ortalama değer 1. sinıflarda 3,59 iken 2. sinıflarda 4,50 olarak çıkmıştır. Şekil 7a ve 7b'de görsel sonuçlar gösterilmiştir.

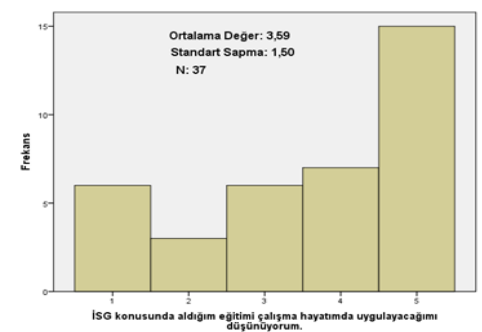

Şekil 7a. Birinci sınıf cevap dağılımı

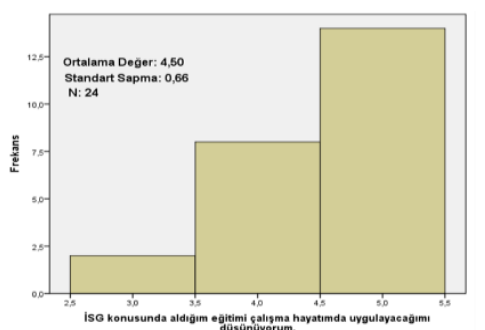

Şekil 7b. İkinci sınıf cevap dă̆glımı

Sorulardan sekizincisi, "ISG için sadece ön lisans değil lisans, yüksek lisans ve doktora düzeyinde de eğitim verilmesi gerektiğini düşünüyorum" sorusudur. Bu soruda 1. sınıf ve 2 . sınıf öğrencilerinin büyük bir kısmı tamamen katılıyorum ve katılıyorum cevabı vermişken 1 . sınıflardan katılmıyorum ve fikrim yok cevaplarının da fazla olduğu görüldü. Diğer eğitim düzeylerinde İSG eğitimlerinin verilmesi gerektiği sorusunda istatistiksel olarak anlamlı bir farkın olmadığı görülmüştür ( $p>0,05)$. Ortalama 
değer 1. sınıflarda 3,51 iken 2. sinıflarda 3,75 olarak çıkmıştır. Şekil 8a ve $8 b^{\prime}$ de görsel sonuçlar gösterilmiştir.

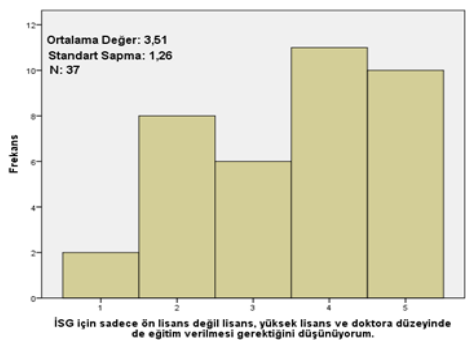

Şekil 8a. Birinci sınıf cevap dağılımı

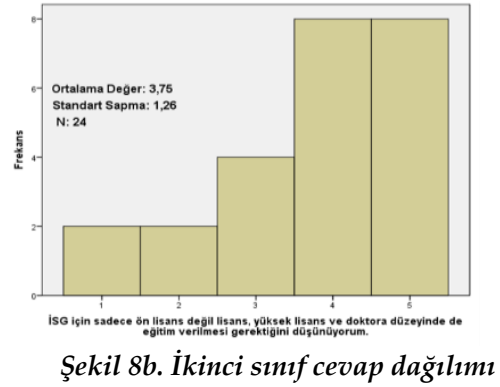

Şekil 8b. İkinci sınıf cevap dağılımı

Sorulardan dokuzuncusu, "ISG'nin sağlanması temel insan haklarından biridir" sorusudur. Bu soruda 1. sınıf ve 2 . sinıf öğrencilerinin büyük bir kısmı tamamen katılıyorum ve katılıyorum cevabı verdiği görüldü. Hem 1. hem de 2 . sınıfların iş sağlı̆̆ ve güvenliği kurallarının temel insan haklarından biri olduğu konusunda hemfikir oldukları görülmektedir. ISG'nin temel insan haklarından biridir sorusunda istatistiksel olarak anlamlı bir farkın olduğu görülmüştür $(\mathrm{p}<0,05)$. Ortalama değer 1 . sınıflarda 3,65 iken 2. sınıflarda 4,58 olarak çıkmıştır. Şekil 9a ve 9b'de görsel sonuçlar gösterilmiştir.

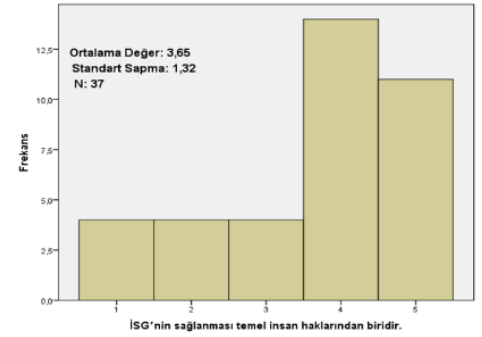

Şekil 9a. Birinci sımıf cevap dağılımı

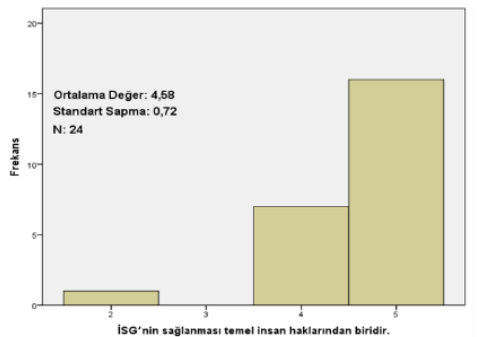

Şekil 9b. İkinci sınıf cevap dă̆ılımı

Sorulardan onuncusu, “ISG'nin ortaöğretim ve lise müfredatında yer alması gerektiğini düşünüyorum" sorusudur. Bu soruda 1. sınıf öğrencilerinin büyük bir kısmı katılmıyorum cevabı verdiği görüldü. 2. sınıf öğrencilerinde tamamen katılıyorum, katılıyorum ve katılmıyorum cevaplarının fazla olduğu görülmüştür. İSG'nin ortaöğretim ve lise müfredatında 
yer alması sorusunda istatistiksel olarak anlamlı bir farkın olmadığı tespit edildi ( $p>0,05)$. Ortalama değer 1. siniflarda 3,19 iken 2. sinıflarda 3,42 olarak çıkmıştır. Şekil 10a ve 10b'de görsel sonuçlar gösterilmiştir.

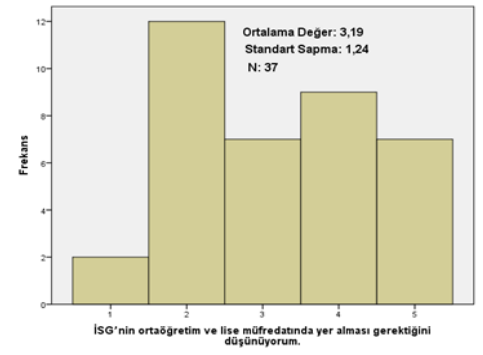

Şekil 10a. Birinci sınıf cevap dağılımı

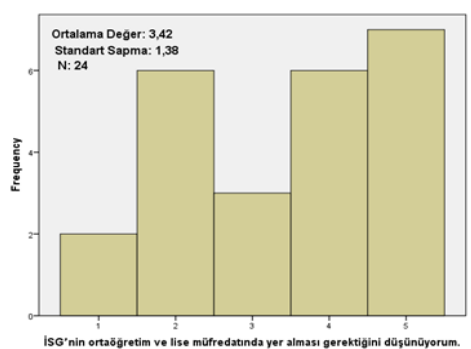

Şekil 10b. İkinci sını cevap dă̆̊lımı

Sorulardan onbirincisi, "ISG eğitimlerinin ve yasal mevzuatın iş kazalarını ve meslek hastalığını azalttığını düşünüyorum" sorusudur. Bu soruda 1 . sinıf öğrencilerinin ve 2 . sinıf öğrencilerinin tamamen katılıyorum cevabının baskın olduğu görülmüştür. Yasal mevzuat ve iş kazaları ve meslek hastalıklarının oranı sorusunda istatistiksel olarak anlamlı bir farkın olduğu tespit edildi ( $p<0,05)$. Ortalama değer 1. sinıflarda 3,95 iken 2. sinıflarda 4,75 olarak çıkmıştır. Şekil 11a ve 11 b'de görsel sonuçlar gösterilmiştir.

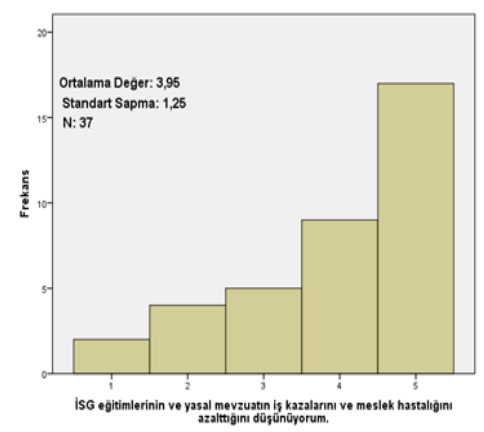

Şekil 11a. Birinci sınıf cevap dağ̊lımı

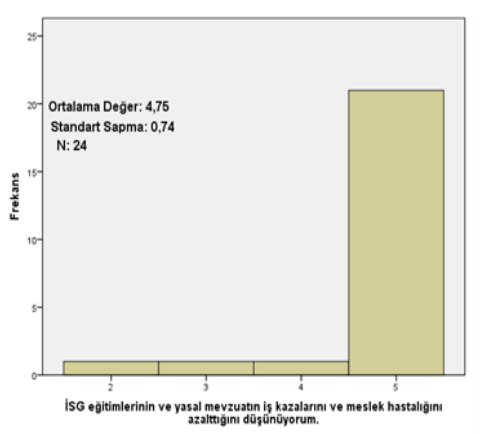

Şekil 11b. İkinci sınıf cevap dă̆ılımı

Sorulardan onikincisi, "her iş yeri aldığı işçiye işe başlatmadan önce işçi sağlığı ve güvenliği eğitimini vermesi gerektiğini düşünüyorum" sorusu- 
dur. Bu soruda 2. sınıf öğrencilerinin tamamen katılıyorum cevabının baskın olduğu, 1. sınıflarda ise birçoğu tamamen katılıyorum ve katılıyorum cevabı verse de diğer cevaplarında verdiği görülmüştür. İşçiye İSG eğitimi verilmesi sorusunda istatistiksel olarak anlamlı bir farkın olduğu tespit edildi $(p<0,05)$. Ortalama değer 1 . sinfflarda 3,81 iken 2 . sınıflarda 4,83 olarak çıkmıştır. Şekil 12a ve 12b'de görsel sonuçlar gösterilmiştir.

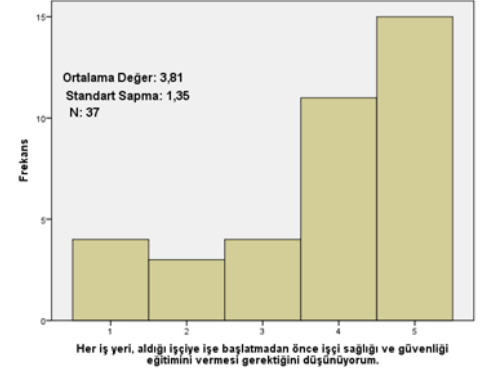

Şekil 12a. Birinci sınıf cevap dağılımı

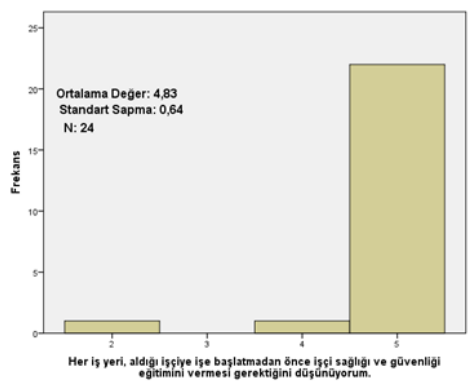

Şekil 12b. İkinci sınıf cevap dağılımı

Sorulardan onüçüncüsü, “Türkiye'de İSG kültürünün oluştuğunu düşünüyorum" sorusudur. Bu soruda hem 1. sinıf hem de 2. sinıf öğrencilerinin düşüncelerinin değişkenlik gösterdiği görülmektedir. İSG kültürünün oluşması sorusunda istatistiksel olarak anlamlı bir farkın olmadığı görülmüştür ( $p>0,05)$. Ortalama değer 1. sinıflarda 2,92 iken 2. sinıflarda 2,50 olarak çıkmıştır. Şekil 13a ve 13b'de görsel sonuçlar gösterilmiştir.

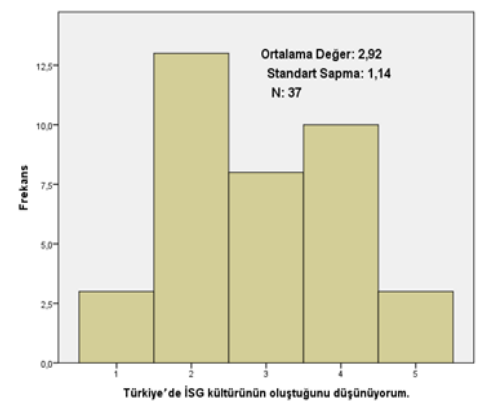

Şekil 13a. Birinci sınıf cevap dă̆ılımı

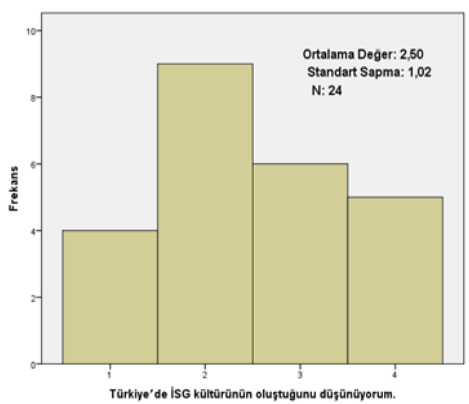

Şekil 13b. İkinci sınıf cevap dă̆ılımı 
Sorulardan ondördüncüsü, "başka bir programı kazanmış olsaydım bile İSG dersinin kazandığım programda zorunlu olmasını isterdim" sorusudur. İSG dersinin zorunlu olması sorusunda istatistiksel olarak anlamlı bir farkın olduğu görülmüştür $(\mathrm{p}<0,05)$. Ortalama değer 1 . sınıflarda 3,14 iken 2. sınıflarda 3,71 olarak çıkmıştır. Şekil 14a ve 14b'de görsel sonuçlar gösterilmiştir.

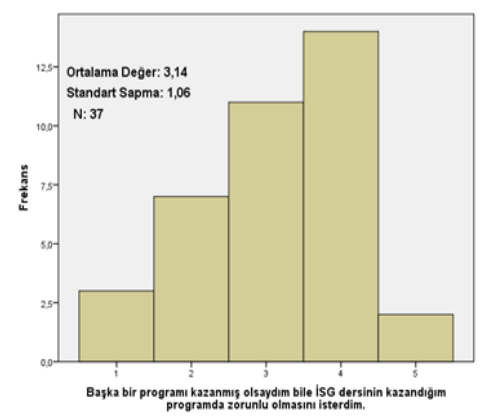

Şekil 14a. Birinci sınıf cevap dağılımı

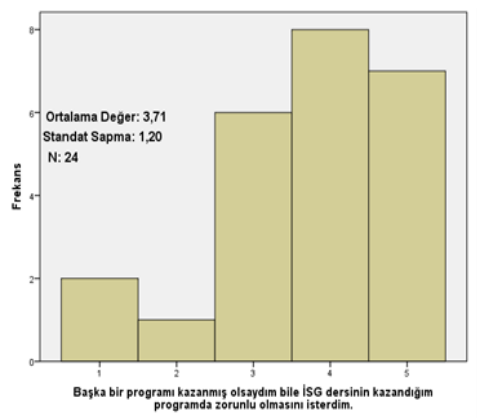

Şekil 14b. İkinci sınıf cevap dağılımı

Sorulardan onbeşincisi, “İSG bölümünde okutulan müfredatın İSG farkındalığ1 konusunda yeterli olduğunu düşünüyorum" sorusudur. 1. sınıflarda fikrim yok cevabı baskınken 2. sınıflarda katılıyorum cevabı baskındır. İSG programında okutulan müfredat ve İSG farkındalığı sorusunda istatistiksel olarak anlamlı bir farkın olmadığı tespit edildi $(p>0,05)$. Ortalama değer 1. sınıflarda 3,32 iken 2. sinıflarda 3,42 olarak çıkmıştır. Şekil $15 \mathrm{a}$ ve $15 b^{\prime}$ de görsel sonuçlar gösterilmiştir.

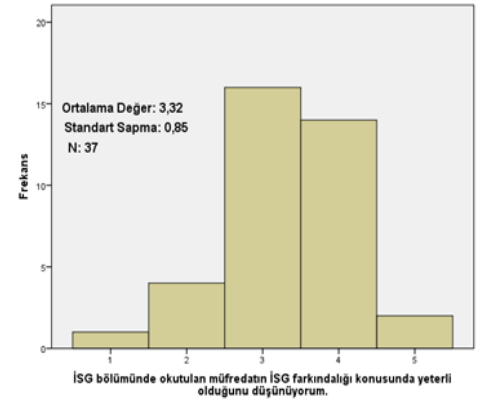

Şekil 15a. Birinci sınıf cevap dă̆ılımı

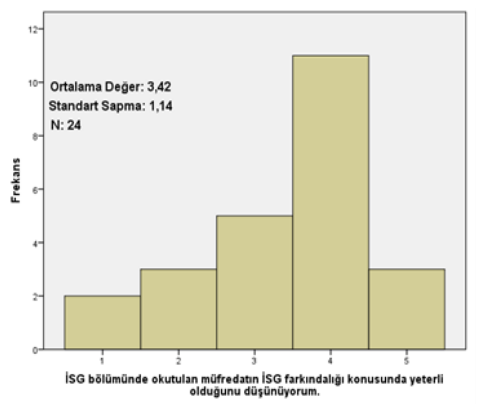

Şekil 15b. İkinci sınıf cevap dă̆ılımı 
Sorulardan onaltıncısı, "ISG kanununun ertelenmesini doğru bulmuyorum" sorusudur. 1. siniflarda baskın olan bir cevap bulunmazken 2. siniflarda tamamen katılıyorum cevabı baskındır. Kanunun ertelenmesi sorusunda istatistiksel olarak anlamlı bir farkın olduğu görülmüştür $(\mathrm{p}<0,05)$. Ortalama değer 1. sinıflarda 3,49 iken 2. sınıflarda 4,08 olarak çıkmıştır. Şekil 16a ve $16 b$ 'de görsel sonuçlar gösterilmiştir.

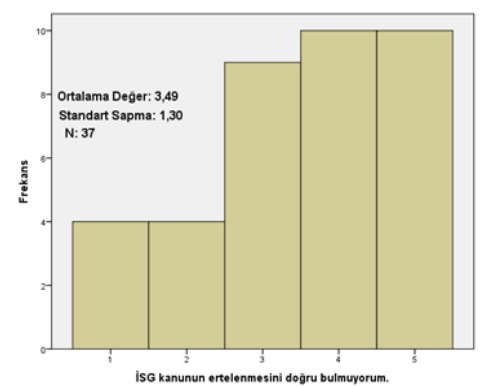

Şekil 16a. Birinci sınıf cevap dă̆ılımı

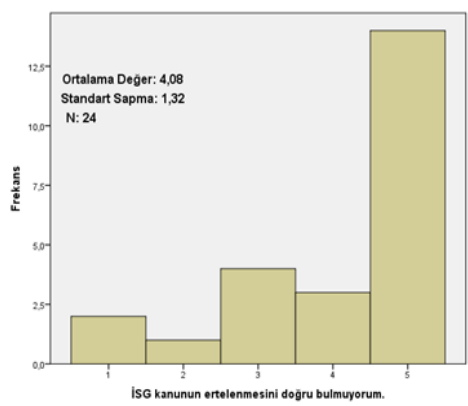

Şekil 16b. İkinci sınıf cevap dă̆ılımı

Sorulardan onyedincisi, "sadece teorik dersler değil iş hayatına uygun pratik derslerinde programda yer alması gerektiğini düşünüyorum" sorusudur. 2. sınıfların ve 1. sınıfların çoğunluğu programda pratik derslerin olması gerektiğini şekil 17 a ve $17 b$ 'de verilen cevaplarla göstermişlerdir. Pratik derslerin programda olması sorusunda istatistiksel olarak anlamlı bir farkın olduğu tespit edildi $(\mathrm{p}<0,05)$. Ortalama değer 1 . sınıflarda 4,03 iken 2. sınıflarda 4,46 olarak çıkmıştır.

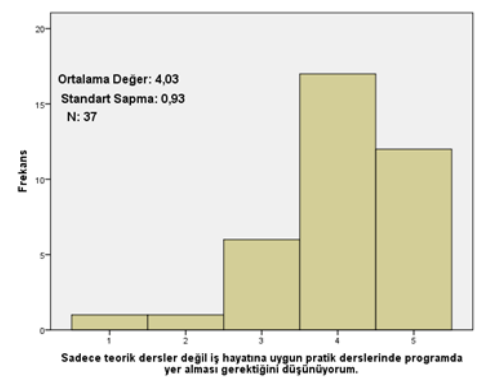

Şekil 17a. Birinci sınıf cevap dă̆ılımı

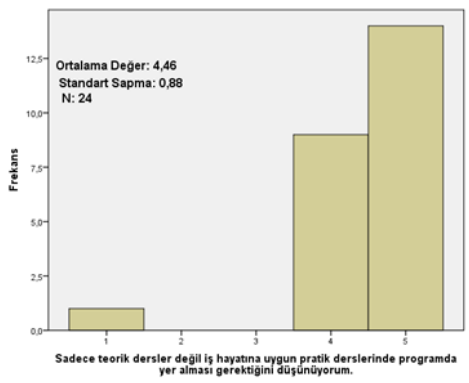

Şekil 17b. İkinci sınıf cevap dağılımı 
Sorulardan onsekizincisi, “6331 sayılı yasanın İSG'nin uygulanması açısından yeterli olduğunu düşünüyorum" sorusudur. 1. sınıflarda fikrim yok cevabı baskınken 2. sinıflarda katılıyorum cevabı ön plandadır. İSG'nin uygulanması sorusunda istatistiksel olarak anlamlı bir farkın olmadığ1 tespit edildi ( $p>0,05)$. Ortalama değer 1. sinıflarda 3,16 iken 2. s1nıflarda 3,29 olarak çıkmıştır. Şekil 18a ve 18b'de görsel sonuçlar gösterilmiştir.

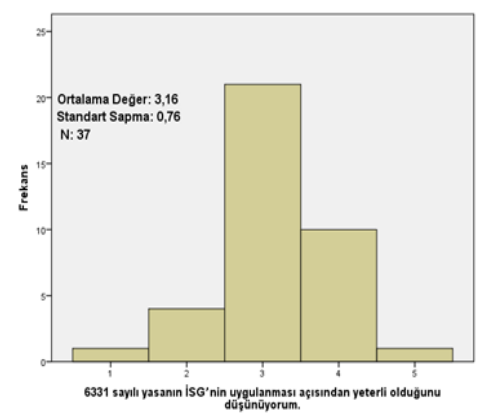

Şekil 18a. Birinci sınıf cevap dă̆ılımı

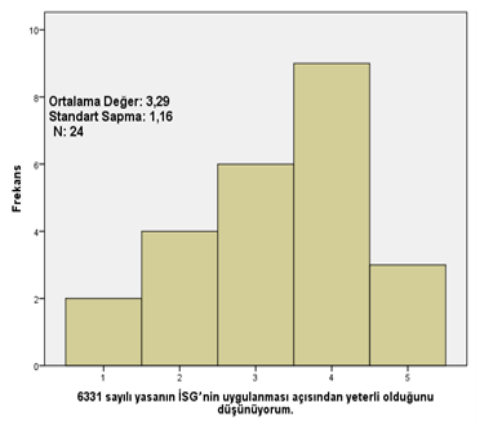

Şekil 18b. İkinci sınıf cevap dağılımı

Sorulardan ondokuzuncusu, "Türkiye'de çalışanların maruz kaldıkları riskler ve bunlarla baş etme yollarında etkin eğitim aldıklarını düşünmüyorum" sorusudur. Hem 1. siniflarda hem de 2. siniflarda katıliyorum cevabının baskın olduğu görülmüştür. Riskler ve baş etme yollarında aldıkları eğitim sorusunda istatistiksel olarak anlamlı bir farkın olmadığı tespit edildi $(p>0,05)$. Ortalama değer 1 . sinıflarda 3,32 iken 2 . sinıflarda 3,75 olarak çıkmıştır. Şekil 19a ve 19b'de görsel sonuçlar gösterilmiştir.

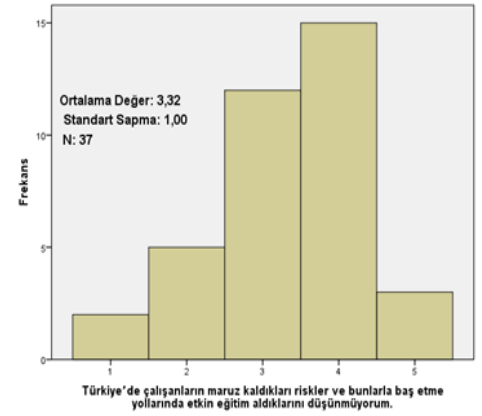

Şekil 19a. Birinci sınıf cevap dağılımı

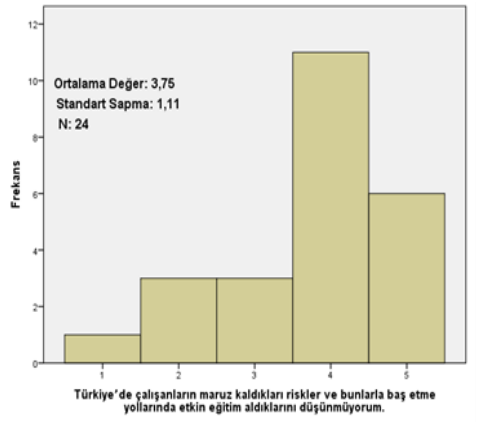

Şekil 19b. İkinci sınıf cevap dağılımı 
Sorulardan yirmincisi, "ISG'nin yalnız çalışma ortamında değil, hayatın her aşamasında olması gerektiğini düşünüyorum" sorusudur. Hem 1. sinıflarda hem de 2. sinıflarda tamamen katılıyorum cevabının baskın olduğu görülmektedir. İSG'nin hayatının her aşamasında olması gerekir sorusunda istatistiksel olarak anlamlı bir farkın olduğu tespit edildi $(p<0,05)$. Ortalama değer 1. sinıflarda 3,78 iken 2. sınıflarda 4,58 olarak çıkmıştır. Şekil 20a ve 20b'de görsel sonuçlar gösterilmiştir.

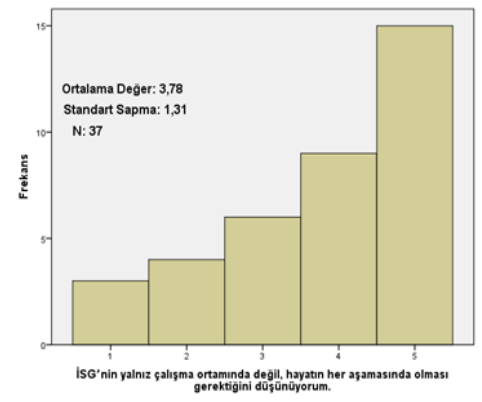

Şekil 20a. Birinci sınıf cevap dă̆ılımı

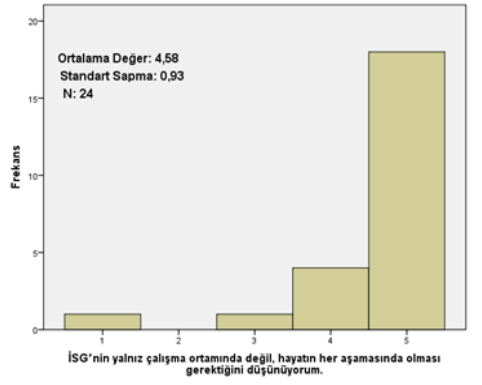

Şekil 20b. İkinci sınıf cevap dağılımı

\section{Tartışma, Sonuç ve Öneriler}

Çalışmada, İSG programında okuyan 2 sınıf öğrencileri ile programdan henüz ders almayan 1. sınıf öğrencilerinin iş sağlı̆̆ 1 ve güvenliğine bakış açlarının eğitim ve öğretim süreci sonucunda nasıl değiştiği incelenmiştir. İSG konusunda oluşturulan strateji, koruma ve önleme kültürünün teşvik edilmesi gerektiğine ve sadece iş yeri ve iş gücü ile sınırlı kalmayarak toplumun tüm kesimlerine hitap etmesinin gerekliliğine inanılmaktadır. Belirlenen stratejinin, sağlık ve risk önleme değerinde bir kültür oluşturmak için öncü olabileceği düşünülebilir. Bu nedenle, her seviyedeki eğitim programlarında, üniversitelerin önlisans ve lisans programları da dahil olmak üzere risk önleme kültürünün geliştirilmesi gerekmektedir.

Verilen eğitim sayesinde bireyler bilgi, davranış ve becerilerini geliştirebilir. Üniversite eğitiminden önceki eğitim kademelerinde İSG eğitimi verilmediğinden dolayı üniversitede alınan İSG eğitimi iş hayatına atılacak olan bireyler için oldukça önem arz etmektedir. Araştırma sorularından birkaçı incelenecek olursa, "ISG konusunda aldığım eğitimi çalışma hayatımda uygulayacağımı düşünüyorum" ve "ISG eğitimlerinin ve yasal 
mevzuatın iş kazalarını ve meslek hastalığını azalttığını düşünüyorum" sorusuna 2. sınıf öğrencilerinin büyük çoğunluğunun "Tamamen Katıl1yorum" cevabı vermesi bu programların üniversitelerde gerekliliğini ve iş hayatına atılacak öğrencilerin ISG konusundaki farkındalıkları için ne kadar önemli olduğunu göstermektedir. Topgül ve Alan (2017) yapmış oldukları anket çalışmasında katılımcılara "Çalışma alanlarında iş güvenliğinin sağlanması temel insan haklarından biridir" ifadesini yöneltmiştir ve bu ifade de İSG dersini almayan katılımcların ortalamas 14,50 , bu oran bu çalışmada 3,65, dersi alan katılımcıların ortalaması 4,52, bu oran bizde 4,58 olarak belirlenmiştir. Bu sonuç öğrencilerin iş sağlı̆̆1 ve güvenliğini çalışma hayatında bir hak olarak gördügünü göstermektedir.

Çelikkalp ve ark. (2017) yapmış oldukları çalışmada hemşirelik öğrencilerine İSG eğitimi öncesi ve sonrasında olmak üzere ön test ve son test uygulamıştır. Katılımcıların İSG kavramını bilme oranı eğitim öncesi \% 21 iken eğitim sonrası \% 82,3 çıkmış ve eğitim sonrasında öğrencilerin iş sağlığı kavramını bilme durumlarının arttığı bulunmuştur ( $\mathrm{p}<0,001)$. Ayrıca eğitim öncesi ve eğitim sonrası İSG bilgi puan ortalamaları sırası ile 3,17 ve 12,67 olarak belirtilmiştir.

Bu çalışmada İSG kavramı ile ilgili ifade "ISSG ile ilgili yasal mevzuatları biliyorum sorusu" idi ve bu soruya dersi almayan katılımcılar açısından ortalama değer 2,73 iken dersi alanlar için ortalama değer 3.71 olarak bulunmuştur. Çelikkalp ve ark. (2017) yapmış olduğu çalışma bu çalışmayı destekler nitelikte olup İSG kavramları ve yasal mevzuatlar konusunda verilen eğitimler öğrencilerde farkındalık yaratmıştır denilebilir.

Özgüler ve Koca'nın (2013) yapmış oldukları çalışmada öğrencilerin \% 84'ü işyerinde İSG eğitimlerinin verilmesi gerektiğini düşünüyorum cevabını vermiştir. Bu çalışmada katılımcılara "İşyerindeki çalışma şartlarının iyileşmesinde İSG eğitimlerinin etkisinin fazla olduğunu düşünüyorum" ifadesi yöneltilmiş ve dersi almayan katılımcılar açısından ortalama değer 3,54 iken, dersi alanlar için bu değer 4,08' dir. Bu sonuç İSG kültürünün öğrenciye üniversitede verilmesi halinde bu kültürün iş hayatında da devam edeceğini göstermektedir. Ayrıca bu çalışmada "İSG konusunda aldığım eğitimi çalışma hayatımda uygulayacağımı düşünüyorum" ifadesinde çıkan ortalama değer sonucu $(3,95)$ farkındalığın eğitim üzerindeki etkisini desteklemektedir. 
Aksoy ve ark. (2013) bazı önlisans programlarında okuyan öğrencilere İSG konusunda meslek yüksekokulundan beklentileri ve aldıkları eğitim ile sahip oldukları İSG bilinçlerinin belirlenmesi amacı ile anket çalışması yapmıştır. Bu çalışmaya göre "İşs sağlığı güvenliğine dikkat etmenin iş verimliliği ve kaliteyi arttırdığını düşünüyor musunuz?" sorusuna katılımcıların cevabı X=2,47 ile "orta" düzeydedir. Bu çalışmada "İSG kurallarından bazılarının iş verimini azalttığını düşünüyorum" ifadesine katılımc1lar açısından ortalama değer 2,43 olarak bulunmuştur. İSG kurallarının iş verimi üzerine etkisi konusunda katılımcıların bilinç düzeyinin yeteri kadar yüksek olmadığ 1 çalışmada ortaya çıkmıştır. İSG konusunda bilinç düzeyinin arttırılması için gerek öğrencilere gerekse program içerisindeki eğitimcilere önemli görev ve sorumluluklar düşmektedir.

Hejduk ve Tomczyk (2015) genç çalışanlarda yaptıkları çalışmada geliştirilen eğitim modeli ile çalışanların alışkanlıklarının değiştiği ve bunu iş yerlerinde uyguladıklarını vurgulamıştır. Yapılan çalışmada "İSG konusunda aldığım eğitimi çalışma hayatımda uygulayacağımı düşünüyorum" ifadesi ile "ISSG programında okutulan müfredatın İSG farkındalığ1 konusunda yeterli olduğunu düşünüyorum" ifadesi sonucu çıkan ortalama değer sırasıyla 3,95 ve 3,37'dir. Çıkan sonuçlar Hejduk ve Tomczyk'ın (2015) yapmış olduğu çalışmayı destekler nitelikte olup uygun bir eğitim modeli geliştirilerek öğrencilerin bu modeli iş hayatında da kullanabilecekleri düşünülebilir.

Reşitoğlu ve ark. (2018) Mersin Sağllk Hizmetleri Meslek Yüksekokulu ikinci sınıfında verilen İSG eğitiminin, öğrencilerin İSG konusundaki bilgi ve farkındalıklarına etkisini incelemiştir. Yapılan çalışmada "İşs sağlı̆̆ı ve güvenliğine dikkat edilmesi iş verimliliğini ve kalitesini artırır", $(p<0,005)$ ifadesi ile istatistiksel olarak anlamlı kabul edilirken, "ISG kurallarından bazılarının iş verimini azalttığını düşünüyorum" ifadesinde $(p>0,005) 1$. ve 2. sınıflar arasında anlamlı bir fark bulunmamıştır. Buna göre öğrencilere iş verimi ile İSG kurallarının doğru orantılı olduğu eğitimlerle daha sık şekilde anlatılmalıdır. Ayrıca İSG kurallarının iş hayatındaki önemini pekiştirecek teknik gezilerin yapılması öğrencilerin konuya bakış açılarını olumlu yönde kuvvetlendirecektir. Buna ek olarak, Reşitoğlu ve ark. (2018) "Tüm çalışanlar iş hayatına başlamadan önce iş güvenliği eğitimi almalıdır" $(\mathrm{p}<0,001)$ ifadesinde olduğu gibi bu çalışmada da "Her iş yeri 
aldığı işçiye işe başlatmadan önce işçi sağllğı ve güvenliği eğitimini vermesi gerektiğini düşünüyorum" $(p<0,005)$ ifadesinde de istatistiki bir anlamlılık söz konusudur. Bu da dersi alan öğrencilerin işe başlamadan önce verilen eğitimlerin işçiler üzerindeki öneminin farkında olduklarını göstermektedir. Yılmaz (2009) çalışmasında belirttiğine göre, Avrupa Birliği eğitim faaliyetlerine ayrılan zaman ve paranın artışı ile 2002-2006 İSG stratejisinde önemli bir başarı göstermiş ve iş kazalarında \% 17 oranında düşüş sağlamıştır, sonraki beş yıllık İSG stratejisinde iş kazalarındaki düşüş oranı \% 25 olarak hedeflenmiştir.

Yapılan tüm bu çalışmalar sonucunda eğitimin İSG farkındalığı konusunda ne kadar önemli olduğunu ve sadece okul hayatında değil iş hayatında da düzenli olarak eğitimlerin tekrar edilmesi gerektiğini vurgulamaktadır. Yine bir başka soruda "İSG kanununun ertelenmesini doğru bulmuyorum" sorusuna 2. sinffların neredeyse tamamı kesinlikle katıl1yorum diyerek sorgulayıcı ve eleştirel tavırlarını ortaya koydukları görülmektedir. Bu tavrın gelişmesinde yıl içerisinde İSG programında görmüş oldukları konular ve bu konuların iş hayatındaki yeri önemli bir rol oynamaktadır. Eğitimler uygun tiplerde ve yeterli miktarda verilmelidir ki birey iş hayatına başladığında günlük tehlike ve risklerle yüzleştiğinde analitik düşünme yeteneğine sahip olsun ve güvenlik bilincine ulaşsın. İSG konusunda alınan eğitimin bir kültüre dönüşmesi sadece iş yerindeki kazaları, maliyeti ve iş yerindeki güvensizliği azaltmakla kalmaz, aynı zamanda işyeri içinde tercih edilme konusunda iyi bir imaj oluşturur. Yetiştirilen bu öğrencilerin İSG eğitimi açısından da yeterli donanıma sahip olarak iş hayatına hazırlanması gerekmektedir. Özellikle 6331 sayılı kanununun hayatımıza girmesiyle birlikte ülkemizdeki meslek yüksekokullarında iş sağlığı ve güvenliği programı sayısında hızlı artış gözlendi. Bu artış İSG alanında kalifiye elemanlara ne kadar ihtiyaç olduğunu göstermektedir.

Özellikle İSG programda okuyan öğrencilerin almış oldukları eğitimleri pratiğe yansıtmaları oldukça önem arz etmektedir. Bunun içinde İSG programında okuyan öğrencilerin bu konuda daha hassas olmaları gerekmektedir. Çünkü bu programdan mezun olan öğrenciler almış oldukları eğitimi direkt olarak çalışma hayatlarına entegre edeceklerdir. Bundan dolayıdır ki yapılan bu ölçek sonucunda uhdemizde verilen eğitimin program kapsamında okuyan öğrenciler üzerinde farkındalık yaratması 
ve bu farkındalığın iki yıl içerisinde İSG kültürüne dönüşmesi amaç edinilen ve istenilen bir durum olmaktadır. Ayrıca yapılan bu çalışma ile İSG programında okuyan öğrencilerin almış oldukları eğitimi ne oranda benimsedikleri belirlenip, öğrencilerin eksik olduğu alanlarda iyileştirme yapılması düşünülmektedir. İSG programında bulunan öğrencilerden 2. sinıf öğrencileri ile ders almayan 1. sınıf öğrencileri arasında istatistiki anlamda fark olduğu bu çalışmada gösterilmiştir. Bu çalışmanın sonuçları ışığında, İSG eğitiminin üniversitelerden önce en azından liselerde farkındalık oluşturması açısından ders olarak eklenmesi sağlanabilir. Böylece öğrenci üniversiteye geldiğinde konu hakkında bilgi sahibi olduğundan dolayı iş kazalarına veya meslek hastalıklarına farklı bir bakış açısı sunabilir.

Yapılan bu çalışma daha fazla örneklem sayısı ile diğer üniversitelerde bulunan İSG programlarında tekrar edilerek her bir üniversitede alınan sonuçlar ile karşılaştırılabilir. Hatta ileri istatistiksel analiz yöntemleri ile yapılan çalışmaların sonuçları genişletilebilir. Böylece bu programlarda verilen eğitimin kalitesi ve öğrenciler üzerindeki etkisi araştırılabilir. Bu araştırma ile birlikte görülen eksiklikler giderilerek tüm üniversitelerde ortak bir müfredat oluşturulabilir. Ayrıca İSG konusunda üniversite sanayi iş birliği yapılarak bu programda okuyan öğrencilerin ek olarak 6 ay veya 1 yıl boyunca, almış oldukları akademik eğitimi pratiğe nasıl dönüştürdükleri incelenerek, eksiklikleri işin mutfağında gidermek adına etkin bir eğitim modelinin geliştirilmesi sağlanabilir.

Özellikle İSG önlisans programlarında görev alan akademisyenlerin öğrencilerinin sempozyum, kongre gibi bilimsel toplantılara katılımlarını teşvik ederek öğrencilerin farkındalıklarının arttırılmasını, Türkiye ve Dünya'da İSG konusundaki gelişmeleri takip etmesini ve gelişen Dünya'ya ayak uydurmasını sağlamalıdır. Bu çalışmada görülmüştür ki verilen eğitim ile birlikte öğrencilerin İSG'ye bakış açılarında değişiklik olabilmektedir. Ancak bu değişikliğin kalıcı olabilmesi için güvenlik kültürünün ailede başlayarak bireye aşılanması gerekmektedir. Ayrıca bu programlarda yapılacak iyileştirmeler beraberinde öğrencilerin uzmanlık konularına daha hakim ve özgüveni yüksek bireyler olarak iş hayatına atılmalarını sağlayacaktır. Böylece iş kazaları ve meslek hastalıklarının azalması sağlanabilecektir. 
EXTENDED ABSTRACT

\section{Effect of Education and Training Given in the Occupational Health and Safety Associate Degree Program on the Perception of Relation Between Occupational Health and Safety}

*

Turan Şahmaran - Hatice Kar - İbrahim Arısal

Mustafa Kemal University

In most undergraduate and associate degree programmes of universities, occupational health and safety courses are given electively or compulsory. These courses are crucial for students to create awareness about occupational health and safety. This awareness taken by favor of education helps students to uncover the culture of prevention in business life. Formation of prevention culture is taken in paralell with education. One of the main reasons of occupational accidents and occupational diseases is lack of education. People who do not have required knowledge and equipment about the job may cause insecure and dangerous behaviours at work.Occupational accidents are inevitable as a result of unsafe behaviours. Occupational accidents usually arise from problems such as lack of training, improper monitoring of inspections, timely maintenance of machinery and equipment, employee judgment, and inattention and carelessness (Sawacha, Shamil and Daniel, 1999).

Some studies have shown that work accidents and occupational disesases will decrease considerably by eliminating these troubles and taking necessary precautions (Training and supervision are main masurement of them). People with intensive working tempo bring health and safety hazards together (Erkan, 2001). These hazards comprise of work accidents and occupational diseases that may directly influence the health of the employee (Parlar, 2008, Kalkıs ve Demir, 2012, Guvercinci, 2005). In this study, it has been aimed to evaluate how viewpoins of second grade students studuying at Occupational Health and Safety (OHS) and first grade 
students who have just come to the university and haven't taken OHS courses can change with education. And also, It has been aimed to evaluate the effectiveness of OSH training given at university level in line with the answers given by the students. Before starting research, the ethics comittee of the study has been taken from Hatay Mustafa Kemal Social Sciences and Humanities Scientific Research and Publication Ethics Board with the decision dated 26.09.2018 and numbered 04 .

\section{Method}

In this study, it has been attempted to state the opinions of 1st and 2nd grade students of OHS programme in respect of occupational health and safety. Totally 61 students, 24 second grade students and 37 first grade students comprise the sample.The proportion of participant students were as so: 44,3 percent of the participants in the sample were female and 55,7 percent were male. $23,0 \%$ vocational high school, $18,0 \%$ health vocational high school, 21,3\% percent general high school and 37,7 \% percent other high schools (Anatolian high schoolls etc.). It has been espied that while selecting OHS associate degree programmes, the rate who have knowledge about department is $42,6 \%$ and the rate of lack of knowledge about department is $57,4 \%$.

Students who have taken OHS trainin in previous business life or during any education has been detected as $27,9 \%$ and students who donot receive any OHS education has been identified as $72,1 \%$. Besides, the average age of 98,4 percent of 1st and 2nd graders is 18-24 and 1,6 percent of it is 25-31. A scale has been applied to first and second grade students of OHS Programme in Hatay Mustafa Kemal University to observe how viewpoints of students can change with the occupational health and safety training. The data of this study have been obtained by Eraslan (2015) validity and reliability studies of University Students' Social Security Perceptions (Topgül and Alan, 2017). The scale of this research is five point likert type scale. The scores for the items of the scale differ from "Strongly Disagree" (1) to "Strongly Agree (5). Thanks to easy to use, coding, measurement, allowing the use of different numbers of options, giving freedom to the researchers in the labeling the options and being easy for the 
participants (Tavakoli, 2012, Spector, 1992) enable frequent usage of Likert-type questions in attitude and opinion researches. Because Likerttype questions are accepted as ordinal data, nonparametric statistical tests have to be utilized in statistical analysis of data obtained in these questions (Turan, Simsek and Aslan, 2015). The questionnaire of the scale have been arranged to enlighten whether the education of second grade students taken in first grade about OHS is effective or not. In this study, KMO values have bee 0,691 and Barlett test results have been found to be significant. Therefore, the research data have been proven to be available for factor analysis., one-dimensional original form of the scale has been acquired in exploratory factor analysis. It has been noticed that this one- dimension can elucidate $26,69 \%$ of total variance. The Cronbach Alpha Coefficient of this study has been calculated as 0,720 . The date obtained in this researh have been analyzed by utilizing SPSS (SPSS (Statistical Package for Social Sciences) for Windows 22,0. Hypotheses of this study are as below:

- H0: There is no significant difference between first and second grade students in OHS Associate Degree Programme about occupational health and safety perception.

- H1: There is a significant difference between first and second grade students in OHS Associate Degree Programme about occupational health and safety perception.

The findings of the Mann-Whitney $U$ test have been examined to determine whether the hypotheses of the study were tested and supported.With this result, it si understood that there is a significant diffference in occupational health and safety perception among the classes of the occupational health and safety students. ( $U=124,50, p=0,006 ; p<0,05)$.

\section{Result}

In this study, it has been shown that there is a statically significant difference between 2nd grade students at OHS Programme and 1st grade students who haven't taken OHS courses yet. In the light of this study results, it can be ensured that OHS training can be added as a course at least in high schools before universities to create awareness. Hence, when the students reach at universities, they can present different point of views to 
work accidents and occupational diseases because they have necessary information about the subject. This study can be compared with the results obtained in each university by repeating in the OSH programs in other universities with more number of samples. Even, it can also be contrasted to other studies that be done with different statistical analysis methods. Thus, the quality of education in this programmes and its effects on students can be ascertained. A common curriculum can be developed in all universities by eliminating shortcomings seen by the aid of current study.

\section{Kaynakça / References}

Akalp, G. ve Karadeniz, N. Y. (2013). İşletmelerde güvenlik kültürünün oluşumunda yönetimin rolü ve önemi. Sosyal Güvenlik Dergisi, 3(2), 96-109.

Aksoy, S., Çevik, B. ve Çakıcıer, N. (2013). Gümüşova Meslek Yüksekokulu'nda iş güvenliği bilincinin belirlenmesi. D.Ü. Bilim ve Teknoloji Dergisi, 1 (1) 69-70.

Alpar, R. (2016). Uygulamalı istatistik ve geçerlik-güvenirlik. Ankara: Detay Yayıncilik.

Asepatori, M. A. A. (2011). Safety awareness at workplace a case study at celcom axiata berhad. Masters thesis. University Utara, Malaysia.

Boileau, P. E. (2016). Sustainability and prevention in occupational health and safety. Industrial Health, 54, 293-295.

Burns, N. ve Grove, S. K. (1993). The practice of nursing research: Conduct, critique and utilization (Second Edition). Elsevier Science Health Science, 28.05.2019, tarihinde https://www.researchgate.net/publication/292391179_Bilimsel_arastirma_sureci_ve_yontem adresinden erişilmiştir.

Büyüköztürk, Ş. (2010). Sosyal bilimler için veri analizi el kitabı. Ankara: Pegem Akademi Yayınları.

Ceylan, H. (2012). Türkiye' deki iş sağlığı ve güvenliği eğitimi sorunlar ve çözüm önerileri. Electronic Journal of Vocational Colleges, 2(2), 94104.

Çelikkalp, Ü, Saraçoğlu, G. V. ve Tokuç, B. (2017). Hemşirelik öğrencilerinin iş sağlı̆̆ ve güvenliği hakkında bilgi düzeylerinin arttırılması. Namık Kemal Medical Journal, 5 (1), 36-43. 
Erkan, N. (2001). Ergonomi. Ankara: Milli Prodüktivite Merkezi Yayını.

Görmüş, A. Ş. ve Bektaş, Ç. (2002). Sektör temsilcilerinin meslek yüksekokulu öğrencilerini algılamalarına yönelik bir araştırma. Afyon Kocatepe Üniversitesi, İI.I.B.F. Dergisi, 4 (2), 19-30.

Güvercinci, M. (2005). İş sağlığ1 ve güvenliği konusunda yeni dönem. $\dot{I}_{s ̧-}$ veren Dergisi, 43 (9), 28-30.

Hale, A. R. ve Hovden, J. (1998). Management and culture: the third age of safety. Occupational injury: Risk, prevention and intervention, (129-166), United Kingdom:Taylor and Francis.

Hejduk, I. ve Tomczyk, P. (2015). Young workers occupational safety knowledge creation and habits. Procedia Manufacturing, 3, 395-401. doi: 10.1016/j.promfg.2015.07.184

International Labour Organization (ILO) (2009). Information on decent work and a health and safety culture, 01.04.2019 tarihinde http://www.ilocarib.org.tt/portal/index.php? adresinden erişilmiştir.

Kalkış, İ. ve Demir, S. (2012). İşverenin iş sağlığ1 ve güvenliği eğitimi verme yükümlülüğü üzerine bir inceleme. Çalışma İlişkileri Dergisi, 3 (1), 23-47.

Kılıç, S. (2016). Cronbach'ın Alfa Güvenirlik Katsayısı. Journal of Mood Disorders, 6 (1), 47-48.

Neira, M. (2010). Healthy workplaces: A model for action. 03.05.2019 tarihi, https://www.who.int/occupational_health/publications/launch_hwp_22april.pdf?ua=1 adresinden erişilmiştir.

Othman, M. B. (2012). Middle-management support and safety training program towards employees safety behavior. Masters thesis. University Utara, Malaysia.

Özgüler, A. T. ve Koca, T. (2013). Meslek yüksekokullarında iş sağlığı ve güvenliği eğitiminin gerekliliği. Electronic Journal of Vocational Colleges, 3 (4), 15-20.

Parlar, S. (2008). Sağlık çalışanlarında göz ardı edilen bir durum: Sağlıklı çalışma ortamı. TAF Prev Med Bull, 7 (6), 547-554.

Reşitoğlu, B., Bağdatoğlu, T., Bahar, L., Ertürk, E., Apaydın, S. ve Pekoğlu, E. (2018). İş sağlığ1 ve güvenliği eğitiminin sağlık hizmetleri öğrencilerinin bilgi ve farkındalıklarına etkisi. IBAD, 3 (2), 459-473. 
Sawacha, E., Shamil, N. ve Daniel, F. (1999). Factors affecting safety performance on construction sites. International Journal of Project Management, 17 (5), 309-315.

Savcı, C., Şerbetçi, G. ve Kılıç, Ü. (2018). Sağlık disiplini öğrencilerinin iş sağlığı ve güvenliği konusunda eğitim alma ve iş kazasına maruz kalma durumu. Sağllk ve Hemşirelik Yönetimi Dergisi, 5 (1), 36-47.

Spector, P. E. (1992). Summated rating scale construction: An introduction. Newbury Park, CA: Sage.

Stellman, J. M. (2012). Encyclopedia of occupational health and safety. Switzerland: International Labour Office.

Tavakoli, H. (2012). A dictionary of research methodology and statistics in applied linguistics. Tahran: Rahnama.

Topgül, S. ve Alan, Ç. (2017). Öğrencilerin iş güvenliği ve iş güvenliği eğitimi algısının değerlendirilmesi. Süleyman Demirel Üniversitesi İktisadi ve İdari Bilimler Fakültesi Dergisi, 22 (2), 587-598.

Turan, İ, Şimşek, Ü. ve Aslan, H. (2015). Eğitim araştırmalarında likert ölçeği ve likert-tipi soruların kullanımı ve analizi. Sakarya Üniversitesi Eğitim Fakültesi Dergisi, 2 (30), 186-203.

World Health Organization (WHO) (1995). Global strategy on occupational health for all: The way to health at work. In: Recommendation of the second meeting of the WHO Collaborating Centres in Occupational Health. 05.05.2019 tarihinde, https://apps.who.int/iris/handle/10665/36845 adresinden erişilmiştir.

World Health Organization (WHO) (2013). The WHO global plan of action on workers' health:2008-2017, In Baseline For Implementation. 01.05.2019 tarihinde, http://www.who.int/occupational health/who_workers_health_web.pdf. adresinden erişilmiştir.

Yılmaz, F. (2009). İş sağllğ1 ve güvenliğinde okul eğitiminin önemi: modern örnekler 1şığında iş sağlığı ve güvenliği lisans eğitiminin ülkemizde uygulanabilirliği. Isş Hukuku ve Ikktisat, 11, 107-139.

Yılmaz, F. (2014). Soma ekseninde Türkiye'de iş sağlığı ve güvenliği üzerine bir değerlendirme. Egiad Yarm, 42, 40-48. 


\section{Kaynakça Bilgisi / Citation Information}

Şahmaran, T., Kar, H. ve Arısal, İ. (2019). İş sağlığı ve güvenliği ön lisans programında verilen eğitim ve öğretimin iş sağllğ ve güvenliği algısı üzerine etkisi. OPUS-Uluslararası Toplum Araştırmaları Dergisi , 11(18), 1797-1827. DOI: 10.26466/opus.565166 